\title{
Journalismista ja valistuksesta
}

\section{HANNU REIME}

Sanalla "valistus" - jota Kansanvalistusseura kantaa nimessään - on pitkään ollut korvissani myönteinen kaiku. Se vie ajatukset 1700 -luvun eurooppalaiseen aatemaailmaan ja modernin maailman syntyyn: upplysningstiden, die Aufklärung, les Lumières, Enlightenment. Sana tuo mieleen Denis Diderot'n ja filosofiset encyclopedistit Ranskassa, David Humen, Adam Smithin ja skottilaisen valistuksen, Immanuel Kantin, Wilhelm von Humboldtin ja muut aika-

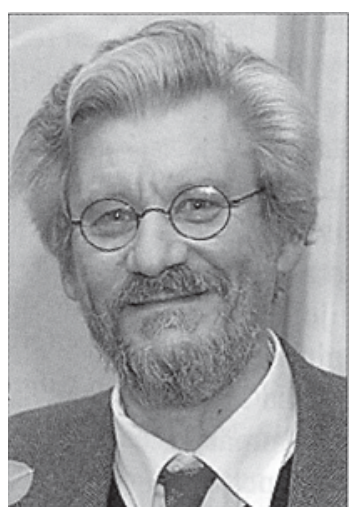
kauden hahmot ja heidän luomansa henkisen ilmapiirin. Silloin kyseenalaistettiin - ensimmäisen kerran uutena aikana - ylhäältä annetut totuudet, jotka sitä ennen oli esitetty jumalansanana. Ihmisiä kehotettiin ajattelemaan itsenäisesti omilla aivoillaan. Tällaista asennetta suositeltiin sen ajan sivistyneistölle. Kansanvalistuksesta oltiin tietenkin vielä kaukana, mutta senkin aika tuli noin sata vuotta myöhemmin.

Kun aloitin työni radiotoimittajana Yleisradion uutisissa 42 vuotta sitten, Yleisradio ja tavallaan koko julkinen elämä ja kulttuuri Suomessa olivat mielenkiintoisessa leikkauspisteessä. Voisi sanoa, että siinä törmäsi yhteen - tai leikkasi toisiaan kaksi erilaista käsitystä valistuksesta. Toinen ja ajallisesti vanhempi oli 1950-luvun Yleisradio: autoritaarinen instituutio, joka sen aikaisen koululaitoksen tavoin syötti tietoa ja sivistystä ylhäältä alas, vähän niin kuin Seitsemän veljeksen lukkari, joka paukutti aa-pee-seetä veljesten paksuihin kalloihin. Voi hyvinkin olla, että huomattava joukko suomalaisia oppi vihaamaan "sinfonioita" konserttimusiikin pakkosyötön johdosta 50-luvulla. "Kevyt” musiikki oli säännösteltyä vähän niin kuin ylellisyystavarat pula-ajan viimeisinä vuosina. Iskelmämusiikkiin - sekä hyvään että huonoon tarttui kielletyn hedelmän houkutteleva maku.

Silloinen käsitys valistuksesta kuului aikaan, jolloin luokkaerot näkyivät ulospäin tyylissä, kulttuurissa ja elämäntavoissa, nykyisinhän työn ja pääoman ristiriita - todellinen ja kouriintuntuva - peittyy kasvottomien markkinavoimien näennäiseen anarkiaan ja suuryhtiöitten totalitaariseen vallankäyttöön. 1950-luvun Yleisradio heijasteli porvarillisen Suomen arvoja, mutta on mielenkiintoista, että ylhäältä johdettu "kansan sivistämisen" ihanne ei ollut kovin kaukana bolševistisesta komissaariajattelusta: me tiedämme, mikä on parasta kansalle ja työläisille. Jos Kronstadtin matruusit eivät ole samaa mieltä, sen pahempi heille.

Yleisradion ohjelmapolitiikka muuttui 1960-luvun puolivälissä. Avattiin ikkunoita maailmaan, ja vallalle pääsi - ainakin hetkeksi - toisenlainen käsitys valistuksesta, käsitys, jonka mukaan kuuntelija ei ole vain passiivinen vastaanottaja, vaan henkilö - tai pikeminkin kansalainen - joka muodostaa itsenäisesti käsityksensä maailmasta, ja jolle - huomattakoon myös tämä - Yleisradio ei ole ainoa tietolähde maailmassa. Ajatus muotoiltiin uudessa ohjelmatoiminnan säännöstössä niin, että Yleisradion tehtävänä ei ole tarjota yleisölleen valmista maailmankuvaa tai maailmankatsomusta, vaan "maailmankuvan rakennusaineita", elementtejä, joista kuuntelija tai katselija voi muodostaa itse oman käsityksensä maailmasta, siis maailmankuvan ja sitä kautta myös maailmankatsomuksen, käsityksen siitä, millainen maailma on, sekä myös omat henkilökohtaiset arvot - millainen tämän ihmisten maailman pitäisi olla. Tätä kutsuttiin "informatiiviseksi ohjelmapolitiikaksi”. Historioitsijoitten tehtävänä on arvioida, kuinka hyvin tai huonosti sen toteuttamisessa onnistuttiin. Mutta jo pelkkä tavoite osoittaa, että nykyisin usein mollattu ja aikoinaankin paljon parjattu "Repo-radio" ei ollut mikään yhden totuuden torvi.

Informatiivisen ohjelmapolitiikan teesejä muotoiltiin myöhempinä vuosikymmeninä uudelleen. Tällaisille, kieltämättä hieman byrokraattisesti ja virkamiesmäisesti kootuille dokumenteille ei enää nykyisessä kymmenien kanavien radiotoiminnassa panna sellaista painoa kuin ennen. Luulisin, että 
ne on melkein unohdettu pölyttymään arkistojen hyllyille. Nykyisin puhutaan "sisällöntuotannosta” aivan kuin kysymyksessä olisi jokin uusi asia, aivan kuin journalismissa ei aikaisemmin olisi ollut sisältöä lainkaan. Ellen ole aivan väärässä niin ohjelmatoiminnan säännöstöihin lisättiin myöhemmin - tai ainakin haluttiin lisätä - informatiivisuuden rinnalle toinen ohjelmien sisältöä säätelevä termi, uusi normi: ohjelmien tuli olla paitsi "informatiivisia” myös "kiinnostavia”.

\section{$\mathrm{M}$} ihin tässä yhteydessä haluttiin viitata sanalla ”kiinnostavuus”? Käsittääkseni kyseessä oli eräänlainen koodisana, jolla itse asiassa tarkoitettiin samaa kuin sensaatiomaisuus: sex, crime, and violence niin kuin asian voi englanninkielisin iskusanoin ilmaista - ja tietenkin myös gossip, juoruilu: kuka eroaa kenestäkin, kuka on kenenkin kanssa, kuka avaa sielunsa kaiken kansan arvioitavaksi.

Mielestäni halu lisätä "kiinnostavuus" "informatiivisuuden" rinnalle ohjelmapoliittiseksi periaatteeksi sisälsi kaksi julkilausumatonta oletusta. Molemmat heijastavat kannattajiensa elitististä halveksuntaa ns. suurta yleisöä kohtaan. Toinen niistä on käsitys, että rikokset, väkivalta, seksi ja juoruilu olisivat aiheita, jotka kiinnostavat yleisöä eniten, enemmän kuin pyrkimys antaa rehellinen kuva maailmasta, mihin kuuluu esimerkiksi poliittisen ja taloudellisen vallankäytön kriittinen käsittely.

Toinen ja oikeastaan mielenkiintoisempi ennakko-oletus tässä on se, että "informatiivisuus" tarkoittaa suurin piirtein samaa kuin "tylsyys". Myös tässä heijastuu suurta yleisöä halveksiva elitistinen maailmankuva. Se on lopultakin vain 1950-lukuun kuuluneen sivistyksen ”pakkosyötön” kääntöpuoli.

E haluaisi tehdä omista kokemuksistani mitään yleistyksiä, mutta minua on kuluneitten vuosikymmenien aikana silloin tällöin kutsuttu luennoimaan tai alustamaan keskustelua niistä lähinnä ulkomaantapahtumia ja kansainvälistä politiikkaa sivuavista kysymyksistä, joita olen journalistisessa työssäni käsitellyt ja joutunut asioitten pakosta käsittelemään. En voi sanoa, että kirjastot ja muut kokoushuoneet olisivat olleet kuulijoista täyteen pakattuja, mutta keskustelu on aina ollut erittäin vilkasta ja osanottajat ovat usein olleet erittäin hyvin perillä käsitellyistä asioista, toisinaan - eikä suinkaan niin harvoin - paremmin kuin luennoitsija itse.

Tällaiset tilaisuudet ovat olleet hyvin valaisevia ja saaneet minut vakuuttuneeksi siitä, että Suomessa on paljon ihmisiä, jotka ovat vakavasti kiinnostuneita maailmasta ja maailmantapahtumista. Tämä on vahvistanut käsitystäni siitä, että 1960luvun "informatiivinen ohjelmapolitiikka” on ajatuksena kaikkea muuta kuin vanhentunut. Aktiivinen kansalainen on ennen kaikkea hyvin informoitu kansalainen - niin tai oikeastaan pitäisi sanoa aktiivisessa verbinmuodossa "hyvin informoitunut”, tieto ja valitushan eivät ole vain jotakin ylhäältä annettua, joka passiivisesti otetaan vastaan. Kuka opettaa opettajia, kysyi eräs tunnettu 1800luvun vallankumouksellinen ajattelija. Kysymys on edelleen yhtä ajankohtainen kuin silloinkin. Opettaminen on myös oppimista.

Yleisradion pitkäaikainen ulkomaantoimittaja Hannu Reime sai Kansanvalistusseuran palkinnon 2007. Reime piti nyt julkaistun puheenvuoronsa palkinnonluovutustilaisuudessa 29.11.

Hannu Reimen ulkomaanraportteja, uutispakinoita ja artikkeleita vuosikymmenten varrelta löytyy vaivattomasti googlaamalla Hannu Reimen nimellä muiden muassa osoitteista http://www.lausti.com/ newsnews/vanhat.htm/ ja http//www.lausti.com/ articles/reimecont.html. 